Provided for non-commercial research and education use. Not for reproduction, distribution or commercial use.

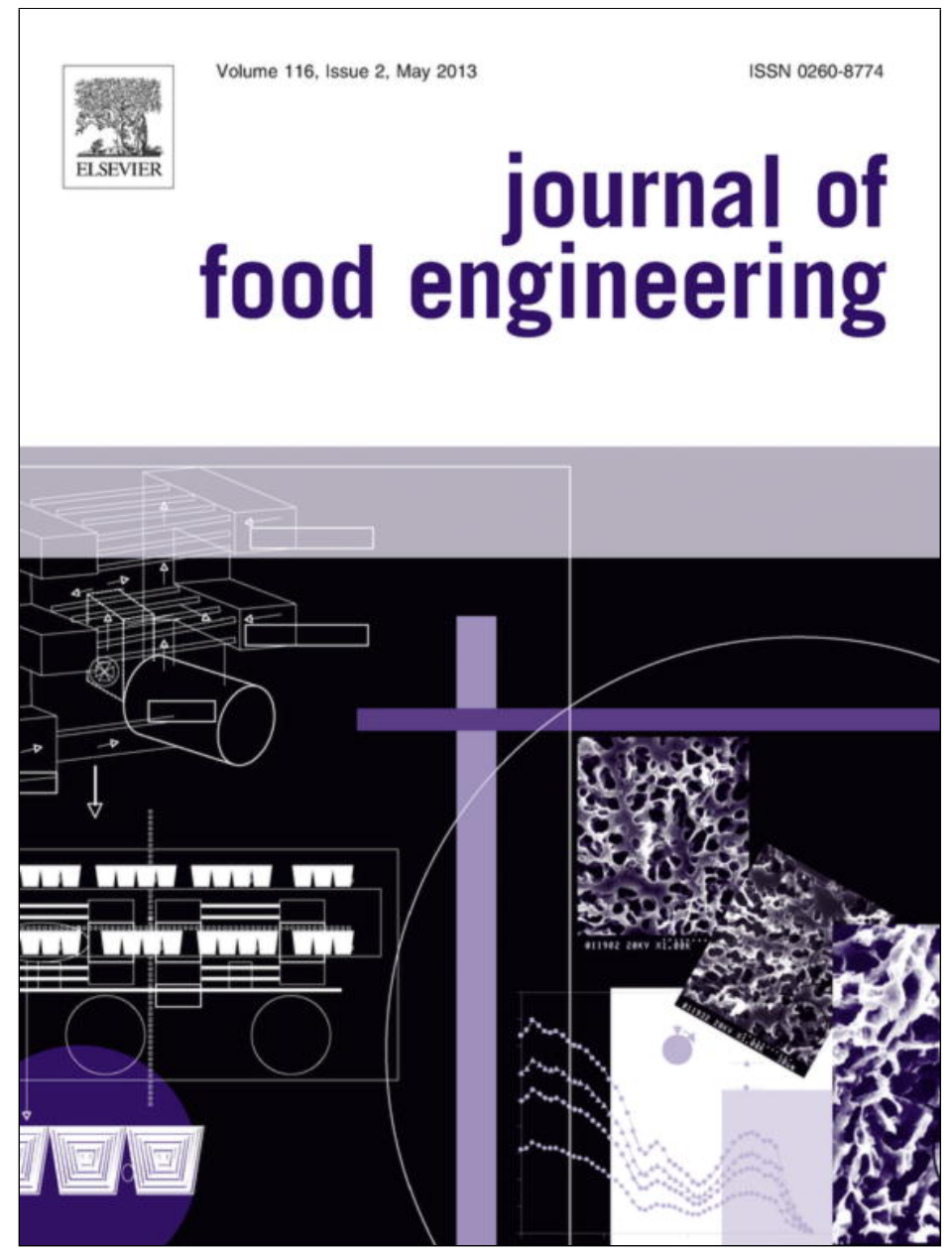

This article appeared in a journal published by Elsevier. The attached copy is furnished to the author for internal non-commercial research and education use, including for instruction at the authors institution and sharing with colleagues.

Other uses, including reproduction and distribution, or selling or licensing copies, or posting to personal, institutional or third party websites are prohibited.

In most cases authors are permitted to post their version of the article (e.g. in Word or Tex form) to their personal website or institutional repository. Authors requiring further information regarding Elsevier's archiving and manuscript policies are encouraged to visit:

http://www.elsevier.com/copyright 


\title{
Kinetics of ascorbic acid degradation in fruit-based infant foods during storage
}

\author{
Vicente Bosch ${ }^{\mathrm{a}}$, Antonio Cilla ${ }^{\mathrm{a}}$, Guadalupe García-Llatas ${ }^{\mathrm{a}}$, Victoria Gilabert ${ }^{\mathrm{b}}$, Rafael Boix ${ }^{\mathrm{b}}$, \\ Amparo Alegría a,* \\ ${ }^{a}$ Nutrition and Food Science Area, Faculty of Pharmacy, University of Valencia, Avda. Vicente Andrés Estellés s/n, 46100 Burjassot, Valencia, Spain \\ ${ }^{\mathrm{b}}$ ALNUT, S.L. Calle Baleares, Parcela A3, Pol. Ind. Poyo de Reva, 46394 Ribarroja, Valencia, Spain
}

\section{A R T I C L E I N F O}

\section{Article history:}

Received 18 June 2012

Received in revised form 22 November 2012

Accepted 1 December 2012

Available online 8 December 2012

\section{Keywords:}

Ascorbic acid

Kinetics

Storage

Shelf-life

Fruit-based infant foods

\begin{abstract}
A B S T R A C T
The kinetics of ascorbic acid (AA) degradation in a fruit-based beikost product added with AA were determined after storage at $4,25,37$ and $50{ }^{\circ} \mathrm{C}$ during $4,8,12,16$ and 32 weeks in plastic polypropylene/ethylene-vinyl alcohol vacuum packaging. It was confirmed that AA degradation followed an Arrhenius first-order kinetics, with an activation energy of $20.11 \pm 0.33 \mathrm{kcal} \mathrm{mol}^{-1}$. No AA losses at $4{ }^{\circ} \mathrm{C}$ were recorded during the entire storage period. In contrast, a time- and temperature-dependent decrease $(p<0.05)$ in AA was observed at the other tested temperatures - the degradation rate decreasing from $50{ }^{\circ} \mathrm{C}$ to $25^{\circ} \mathrm{C}$, as expected. AA percentage retention at the end of storage ranged between $6.4 \%\left(50{ }^{\circ} \mathrm{C} /\right.$ 16 weeks) and $100.9 \%\left(4^{\circ} \mathrm{C} / 32\right.$ weeks $)$.
\end{abstract}

(c) 2012 Elsevier Ltd. All rights reserved.

\section{Introduction}

Together with human milk or infant formulas, infants from 4 to 6 months of age onwards receive complementary feeding (beikost) to satisfy their nutritional demands (Agostoni et al., 2008). In recent years there has been an increase in the consumption of beikost-related products produced at industrial scale. Specifically, in Spain during 2010, the sale of infant foods totaled about 29.5 million kilograms. Of this total, the products most demanded by consumers have been of a fruit-based nature, accounting for $41.8 \%$ of the total infant food sales. These kinds of products are usually acquired in hypermarkets and supermarkets, representing more than $85 \%$ of the total sales (Mercasa, 2011).

Fruit-based infant foods, together with cereals, are the first foodstuffs introduced in the diet of the unweaned infant, contributing to cover the vitamin requirements, especially those of vitamin C. Ascorbic acid (AA) has multiple biochemical roles, though it primarily acts as a water-soluble antioxidant in the human body (Martí et al., 2009). The recommended dietary allowances for vitamin $C$ are 40 or $50 \mathrm{mg} /$ day in unweaned infants from 0 to 6 or 7 to 12 months of age, respectively (Food and Nutrition Board, 2010). On the other hand, the maximum amount of added vitamin $\mathrm{C}$ allowed in fruitbased infant foods is $125 \mathrm{mg} / 100 \mathrm{kcal}$ (Directive 2006/125/CE).

To guarantee the quality of processing, storage, and the nutritional and organoleptic qualities of these products, use has been

\footnotetext{
* Corresponding author. Tel.: +34 963544907; fax: +34 963544954.

E-mail address: amparo.alegria@uv.es (A. Alegría).
}

made of AA content as a control parameter (Canet Parreño, 1996; Polydera et al., 2005). The degradation of AA in foods can take place via aerobic and/or anaerobic pathways, and depends on factors such as oxygen, heat, light, water activity, the presence of metallic ions such as $\mathrm{Cu}^{2+}$ and $\mathrm{Fe}^{3+}$, temperature and storage time (Santos and Silva, 2008; Martí et al., 2009). In this sense, in a model system of UV-treated apple juice, it has been reported that AA degradation increases in the $\mathrm{pH}$ range between 3.3 and 5.5, while an increase in glucose and sucrose contents exerts no effect (Tikekar et al., 2011). In addition, it is well known that AA content declines during storage, especially in thermally treated foods, with the consequent formation of non-enzymatic browning compounds, which serve as indicators of organoleptic quality loss of the product (Uddin et al., 2002).

The degradation of AA usually follows first-order kinetics, as reported in several studies: a mixed pasteurized orange-carrot juice stored for 6 weeks at $4{ }^{\circ} \mathrm{C}$ or stored for 5 weeks at $10^{\circ} \mathrm{C}$ (Rodrigo et al., 2003); orange juice in polypropylene bottles or flexible pouches stored for 4 or 8 weeks at $0,5,10$ and $15^{\circ} \mathrm{C}$ (Polydera et al., 2003); pasteurized fresh Navel orange juice stored at 0,5 , 10,15 and $30^{\circ} \mathrm{C}$ (Polydera et al., 2005); citric juices made from concentrate stored for 8 weeks at 28,37 and $45^{\circ} \mathrm{C}$ (Burdurlu et al., 2006); and non-pasteurized lemon juice stored for 12 weeks at $3{ }^{\circ} \mathrm{C}$ and $27{ }^{\circ} \mathrm{C}$ (Abbasi and Niakousari, 2007). To our knowledge, the literature offers only one study addressing the kinetics of AA degradation in baby foods made from apple puree stored for 60 weeks at 23,30 and $37^{\circ} \mathrm{C}$ (Palazón et al., 2009), and this study likewise reported first-order AA degradation kinetics. 
Considering the scarce information available on vitamin $\mathrm{C}$ degradation in fruit-based baby foods, and the growing interest in knowing the specific AA degradation kinetics with a view to establishing the corresponding time-temperature dependency and thus adapt the shelf-life of these products, the present study was designed to determine the AA degradation kinetics in a fruit-based baby food stored for 32 weeks at $4,25,37$ and $50{ }^{\circ} \mathrm{C}$.

\section{Materials and methods}

\subsection{Samples}

A fruit-based beikost product with added AA containing pear fruit puree (22\%), tangerine juice (22\%), apple fruit puree (22\%), banana fruit puree (16.5\%), carrot puree (10\%), grape juice from concentrate, corn starch and vitamin C (as stated on the label of the product) was manufactured by ALNUT, S.L., a new Spanish company on the baby food market.

Ingredients were mixed to homogenize the product and a heat treatment (above $85^{\circ} \mathrm{C}$ ) was carried out to hot-filling. The products were packed in commercial $130 \mathrm{~g}$ plastic polypropylene/ethylenevinyl alcohol $(\mathrm{PP} / \mathrm{EVOH})$ vacuum packaging. Once packaged, they were pasteurized in an autoclave to a minimum of $6.3 f_{0}$ to ensure microbiological stability throughout the shelf-life.

The samples were maintained in their original containers until analysis. The initial nutritional composition of the samples was analyzed, and their AA content was determined at baseline (time 0 ) and after $4,8,12,16$, and 32 weeks at $4,25,37$ and $50{ }^{\circ} \mathrm{C}$. Measurements were carried out in triplicate in a pool of different samples of the same batch. The temperature was controlled with a Selecta Incubator $\left( \pm 1^{\circ} \mathrm{C}\right)$.

\subsection{Methods}

\subsubsection{Nutritional composition}

The nutritional composition was determined by the following procedures:

\footnotetext{
Moisture: Indirect method for drying $\left(100^{\circ} \mathrm{C} \pm 5^{\circ} \mathrm{C}\right.$ ) (Hardman, 1989).

Ashes: dry mineralization $\left(450^{\circ} \mathrm{C} / 24 \mathrm{~h}\right)$ (Ruiz et al., 1995).

Proteins: Kjeldahl method. Method 960.52 (AOAC, 2000).

Sucrose, glucose, fructose: Enzymatic method with determination by molecular absorption spectrophotometry UV. Enzymatic Bioanalysis Boehringer Mannheim/R-Biopharm (Cat. No. 10716 260 035).

Starch: Enzymatic method with determination by molecular spectrophotometry UV. Enzymatic Bioanalysis Boehringer Mannheim/R-Biopharm (Cat. No. 10207748 035).

Total dietary fiber: Total Dietary Fiber Assay Kit. Sigma TDF100AKit, based on Method 985.29 (AOAC, 2000).

Fat: Gravimetrically after extraction according to Folch et al. (1957) modified by Boselli et al. (2001).

Iron, zinc and sodium: Flame atomic absorption spectrophotometry upon white dry ashes and dissolution of the latter with hydrochloric acid (in the case of iron and zinc) or nitric acid (sodium) (Ruiz et al., 1995).
}

\subsubsection{Ascorbic acid determination}

AA was determined as described by Official Method 967.21 (AOAC, 2000), with minor changes. For each analysis, a weight of $2 \mathrm{~g}$ of the previously homogenized sample was placed in a $10 \mathrm{~mL}$ amber glass tube, followed by the addition of $4 \mathrm{~mL}$ of metaphosphoric acid-acetic acid solution [6 $\mathrm{g}$ of metaphosphoric acid (Chip ACS, Sigma-Aldrich, Steinheim, Germany) with $16 \mathrm{~mL}$ of glacial acetic acid (Merck, Darmstadt, Germany) and diluted to $200 \mathrm{~mL}$ with Millipore-MilliQ distilled-deionized water (freshly prepared)], and the mixture was homogenized during $2 \mathrm{~min}$ at $2500 \mathrm{rpm}$ followed by a purge with a flow of $\mathrm{N}_{2}$. Then, the samples were titrated with indophenol standard solution [50 mg 2,6dichloroindophenol sodium salt (Merck, Darmstadt, Germany) in $50 \mathrm{~mL}$ of distilled-deionized water to which $42 \mathrm{mg} \mathrm{NaHCO}_{3}$ (Merck, Darmstadt, Germany) had been added and diluted to $200 \mathrm{~mL}$ with distilled-deionized water]. At the end point, excess unreduced dye is rose pink in acid solution. Indophenol standard solution was titrated rapidly with $1 \mathrm{~mL}$ AA standard solution [50 mg AA reference standard 99\% purity (Panreac, Barcelona, Spain) diluted to $50 \mathrm{~mL}$ with metaphosphoric acid-acetic acid solution]. Blanks were analyzed in parallel.

The official method for AA determination was adapted to the sample. Sample weights were calculated to obtain around 40$60 \mathrm{mg}$ of AA, testing with 2 and $4 \mathrm{~g}$ of sample. The volume $(2,4$, 6 and $8 \mathrm{~mL}$ ) of the extracting solution (metaphosphoric acid-acetic acid solution) was adapted to secure the maximum extraction of AA. Finally, the selected conditions comprised a volume of $4 \mathrm{~mL}$ for the extraction of $2 \mathrm{~g}$ of sample.

Products containing ferrous, stannous and cuprous compounds produce interferences in this method, resulting in overestimation of the AA contents. To determine these possible interferences, two drops of methylene blue (Panreac, Barcelona, Spain) were added to $2 \mathrm{~g}$ of sample with $4 \mathrm{~mL}$ of extracting solution. Disappearance of the methylene blue color in 5-10 s indicates the presence of interfering substances. The samples analyzed in this study showed no interferences.

\subsubsection{Kinetics of ascorbic acid degradation}

The order of a reaction in a kinetic model is a parameter that offers a mathematical description of time or concentration dependence. It is useful for predicting the behavior of a particular reaction in a food product, and therefore is suitable for modeling the shelf-life of a product. The best known models referred to shelf-life studies are zero-order reactions that represent a linear evolution (retention or degradation) of the parameter, and first-order reactions that represent an exponential evolution of the parameter (Labuza, 1982; Palazón et al., 2009). The following equations describe the model for zero and first order kinetics:

Zero-order : $[\mathrm{A}]=[\mathrm{A}]_{0}-\mathrm{kt}$

First order : $[\mathrm{A}]=[\mathrm{A}]_{0} \exp ^{-\mathrm{kt}}$

where $[A]$ is the concentration of $A A$ for a fixed storage time and temperature; $[\mathrm{A}]_{0}$ is the initial value of $\mathrm{AA}$ in the sample; $k$ is the reaction rate constant; and $t$ is the storage time (in weeks).

The temperature dependence of AA degradation can be determined by using the Arrhenius equation:

$k=\operatorname{Aexp}^{-\mathrm{Ea} / \mathrm{RT}}$

where $k$ = rate constant; $\mathrm{A}=$ pre-exponential factor; $\mathrm{Ea}=$ activation energy $\left(\mathrm{kcal} \mathrm{mol}^{-1}\right) ; R=$ gas constant $\left(1.987 \mathrm{kcal} \mathrm{mol}^{-1} \mathrm{~K}^{-1}\right)$; and $T=$ absolute temperature $(\mathrm{K})$.

By removing the exponential we have:

$\ln k=\ln \mathrm{A}-\mathrm{Ea} / \mathrm{RT}$

This equation indicates that a plot of $\ln k$ versus the reciprocal of absolute temperature yields a straight line, the slope of which is the activation energy divided by the gas constant $R$. Thus, by studying a reaction and measuring $k$ at two or three temperatures, one can extrapolate with a straight line to a lower temperature and predict the rate of the reaction at the desired lower temperature (Labuza and Riboh, 1982). 


\subsection{Statistical analysis}

A two-way ANOVA was applied to the AA contents in order to detect differences due to the storage temperature $(4,25,37$ and $\left.50{ }^{\circ} \mathrm{C}\right)$ and storage period $(0,4,8,12,16$ and 32 weeks). In addition, one-way ANOVA was also assessed to check the influence of temperatures on the retention of AA percentages. In all cases, data normality was assessed (data not shown). The post hoc LSD test was applied to identify differences that were set at $p<0.05$. In order to afford a predictive model of AA as a function of storage time and temperature, a multiple regression test was applied. The Statgraphics (Centurion XV release 15.2.06; Rockville, MD, USA) statistical software package was used throughout.

\section{Results and discussion}

\subsection{Nutritional composition}

The results obtained referred to the nutritional composition of the fruit-based beikost product are shown in Table 1 .

Total protein content was $0.49 \mathrm{~g} / 100 \mathrm{~g}$. Since the sample is a fruit-based infant food not designated on the label as a meal, there is no regulated maximum protein content (Directive 2006/125/CE). The total carbohydrate contents $(14.43 \mathrm{~g} / 100 \mathrm{~g})$ do not exceed the maximum amount allowed $(25 \mathrm{~g} / 100 \mathrm{~g})$ in desserts or puddings for infants and young children as regulated by the same Directive. Regulations referred to individual carbohydrate contents are not present in the Directive. Likewise, fiber content is not regulated by the Directive, and there are no recommended daily allowance (RDA) specifications for unweaned infants. However, there probably are minimum non-digestible carbohydrate requirements in the first months of life derived from milk or complementary foods. Our sample contained $1.48 \mathrm{~g} / 100 \mathrm{~g}$ of dietary fiber, which is adequate on the basis of the recommendations for a soluble and insoluble fiber intake of $5 \mathrm{~g} /$ day with the introduction of fruit, vegetables and cereals in the second semester (Ballabriga and Carrascosa, 2006). Regarding minerals, the current Directive specifies that the end sodium content of the product should not exceed $200 \mathrm{mg} / 100 \mathrm{~g}$. The concentration in our sample was $12.4 \mathrm{mg} /$ $100 \mathrm{~g}$, which is far below this maximum limit. In the case of iron and zinc, the Directive only specifies Reference Values for Nutrition Labeling of 6 and $4 \mathrm{mg}$, respectively, which implies that the product supplies less than $5 \%$ and $2 \%$, respectively, of each mineral per $100 \mathrm{~g}$.

\subsection{Ascorbic acid determination}

The initial AA content, immediately after the manufacturing process, was $88.1 \mathrm{mg} / 100 \mathrm{~g}$ (Table 2 ). These products supply between 43.1 and $45.4 \mathrm{mg} / 100 \mathrm{kcal}$, and are thus compliant with the maximum vitamin C limit applicable to fruit-based foods (125 mg/100 kcal, according to current legislation). The contents are within the intervals declared for marketed products of this kind.

\subsection{Evolution of ascorbic acid content during storage}

AA evolution during storage and its retention percentages are shown in Table 2 . Samples stored at $37^{\circ} \mathrm{C}$ and $50^{\circ} \mathrm{C}$ were not analyzed at the last sampling point ( 32 week) because they showed marked browning which interfered with the determination (data not shown), and clearly indicated a loss of organoleptic and commercial quality of the product. The randomness (Two-way ANOVA of residuals squared are: factor temperature $p=0.1092$ and factor time $p=0.1424$; since these values are $p>0.05$, this means there
Table 1

Analyzed nutritional composition of the fruit-based beikost (results are expressed as mean \pm standard deviation, $n=3$ ).

\begin{tabular}{ll}
\hline Parameter & $(\mathrm{g} / 100 \mathrm{~g})$ \\
\hline Moisture & $81.29 \pm 0.05$ \\
Ashes & $0.57 \pm 0.06$ \\
Proteins & $0.49 \pm 0.04$ \\
Carbohydrates & $14.43 \pm 1.39$ \\
From which sugars & $12.92 \pm 1.34$ \\
Glucose & $3.64 \pm 0.45$ \\
Fructose & $5.77 \pm 0.56$ \\
Sucrose & $3.51 \pm 0.33$ \\
Starch & $1.51 \pm 0.05$ \\
Dietary fiber & $1.48 \pm 0.08$ \\
Fat & $0.09 \pm 0.01$ \\
Iron $(\mathrm{mg} / 100 \mathrm{~g})$ & $0.25 \pm 0.03$ \\
Zinc $(\mathrm{mg} / 100 \mathrm{~g})$ & $0.07 \pm 0.01$ \\
Sodium $(\mathrm{mg} / 100 \mathrm{~g})$ & $12.40 \pm 0.34$ \\
\hline
\end{tabular}

are homogeneity of variances for a 95\% level of significance) and normality (Chi-square test $p=0.102256$ with a mean value of $2.74324 \times 10^{-7}$ and a standard deviation of 1.13973 ; since $p>0.05$ this means normality for a 95\% level of significance) of the residues was checked previously to perform a two-way ANOVA to the AA contents in order to detect differences due to the storage temperature $\left(4,25,37\right.$ and $\left.50^{\circ} \mathrm{C}\right)$ and storage period $(0,4,8,12,16$ and 32 weeks). The application of two-way ANOVA (temperature and time storage) showed statistically significant differences $(p<0.05)$ in AA content for both factors, with a decrease in AA content in the sample, dependent upon storage time and temperature.

At the end of the storage, the values ranged from $5.6 \mathrm{mg} / 100 \mathrm{~g}$ $\left(50{ }^{\circ} \mathrm{C}\right)$ to $88.9 \mathrm{mg} / 100 \mathrm{~g}\left(4^{\circ} \mathrm{C}\right)$, which represents $\mathrm{AA}$ retention percentages of $6.4 \%$ and $100.9 \%$, respectively. If there are some values of AA retention slightly higher than $100 \%$ at $4{ }^{\circ} \mathrm{C}$ during the whole storage is due to the inter-day precision assays and not to the initial content, since the same sample was analyzed at different time periods and temperatures. In any case, the coefficients of variation found at $4{ }^{\circ} \mathrm{C}$ in the whole study were low and comprised between $0.6 \%$ and $3.6 \%$. No losses in AA during storage at $4{ }^{\circ} \mathrm{C}$ were observed, thus indicating the stability of this compound at the usual refrigeration storage temperature (Table 2 ). The degradation rate order being as follows: $50^{\circ} \mathrm{C}>37^{\circ} \mathrm{C}>25^{\circ} \mathrm{C}$. These findings were also reflected by the percentage retention values, which were inversely related to storage temperature $(63.3 \%, 36.1 \%$ and $6.4 \%$ at 25,37 and $50{ }^{\circ} \mathrm{C}$, respectively) and decreased with the time $(p<0.05)$ as reflected by one-way ANOVA (Table 2$)$.

We observed great discrepancies when samples were stored at $4{ }^{\circ} \mathrm{C}$ in our study (with no degradation of AA during the 32 weeks of storage) versus other results found in the literature at this same storage temperature. In this sense, Polydera et al. (2003) reported AA degradation of up to $50 \%$ in reconstituted orange juice after conventional thermal pasteurization $\left(80^{\circ} \mathrm{C}, 30 \mathrm{~s}\right)$ when stored at $5{ }^{\circ} \mathrm{C}$ during 5 weeks. Likewise, in another study, these same authors reported (Polydera et al., 2005) degradation up to $50 \%$ of the AA in pasteurized $\left(80^{\circ} \mathrm{C}, 60 \mathrm{~s}\right)$ fresh Navel orange juice stored at $5{ }^{\circ} \mathrm{C}$ during 8 weeks. These differences can be explained, at least in part, by the anaerobic atmosphere present in our samples, which were vacuum packaged, while no mention is made in this respect in the abovementioned studies. It is well-known that AA degradation via the anaerobic pathway is meaningless in foods (Martí et al., 2009), what could explain the absence of AA degradation in our study at $4{ }^{\circ} \mathrm{C}$ within this non-oxidative atmosphere. In addition, it has been reported that PP, used by Polydera et al. (2003, 2005), while providing thermal and impact resistance, is a poor gas barrier (Robertson, 1993) - which could explain the significant reduction of $A A$ in these studies. In contrast, samples in the present study were packaged with $\mathrm{PP}$ and $\mathrm{EVOH}$, respectively providing 
Table 2

Ascorbic acid concentrations ( $\mathrm{mg} / 100 \mathrm{~g}$ ) and percentage retention (\%) during storage at different times and temperatures (results are expressed as mean \pm standard deviation, $n=3)$.

\begin{tabular}{|c|c|c|c|c|c|c|c|c|}
\hline \multirow[t]{2}{*}{ Weeks } & \multicolumn{2}{|l|}{$4^{\circ} \mathrm{C}^{1}$} & \multicolumn{2}{|l|}{$25^{\circ} \mathrm{C}^{2}$} & \multicolumn{2}{|l|}{$37^{\circ} \mathrm{C}^{3}$} & \multicolumn{2}{|l|}{$50{ }^{\circ} \mathrm{C}^{4}$} \\
\hline & $\mathrm{mg} / 100 \mathrm{~g}$ & $\%$ & $\mathrm{mg} / 100 \mathrm{~g}$ & $\%$ & $\mathrm{mg} / 100 \mathrm{~g}$ & $\%$ & $\mathrm{mg} / 100 \mathrm{~g}$ & $\%$ \\
\hline $0^{\mathrm{a}}$ & $88.1 \pm 1.8$ & $100.0 \pm 1.8^{1}$ & $88.1 \pm 1.8$ & $100.0 \pm 1.8^{1}$ & $88.1 \pm 1.8$ & $100.0 \pm 1.8^{1}$ & $88.1 \pm 1.8$ & $100.0 \pm 1.8^{1}$ \\
\hline $4^{\mathrm{b}}$ & $87.6 \pm 1.1$ & $99.4 \pm 1.2^{1}$ & $81.6 \pm 1.0$ & $92.6 \pm 1.1^{2}$ & $65.2 \pm 1.3$ & $74.0 \pm 1.5^{2}$ & $51.7 \pm 0.7$ & $58.7 \pm 0.8^{2}$ \\
\hline $8^{\mathrm{b}}$ & $82.2 \pm 0.6$ & $93.3 \pm 0.7^{2}$ & $77.1 \pm 0.8$ & $87.5 \pm 0.9^{3}$ & $55.5 \pm 0.4$ & $63.0 \pm 0.5^{3}$ & $22.0 \pm 0.9$ & $25.3 \pm 1.0^{3}$ \\
\hline $12^{\mathrm{bc}}$ & $88.7 \pm 3.2$ & $100.7 \pm 3.6^{1}$ & $73.0 \pm 1.3$ & $82.9 \pm 1.5^{4}$ & $55.4 \pm 1.7$ & $62.9 \pm 2.0^{3}$ & $7.3 \pm 0.6$ & $8.3 \pm 0.7^{4}$ \\
\hline $16^{\mathrm{c}}$ & $94.1 \pm 2.1$ & $106.7 \pm 2.3^{3}$ & $74.8 \pm 0.8$ & $84.9 \pm 0.9^{5}$ & $31.8 \pm 0.8$ & $36.1 \pm 0.9^{4}$ & $5.6 \pm 0.5$ & $6.4 \pm 0.5^{5}$ \\
\hline $32^{d}$ & $88.9 \pm 0.5$ & $100.9 \pm 0.6^{1}$ & $55.7 \pm 1.29$ & $63.3 \pm 1.5^{6}$ & n. d. & & n. d. & \\
\hline
\end{tabular}

n.d.: Not determined (development of browning)

Different numbers (first line) and letters (first column) indicate statistically significant differences $(p<0.05)$ according to temperatures and time of storage, respectively, based on two-way ANOVA.

Different numbers in the same column (percentage retention) indicate statistically significant differences $(p<0.05)$, based on one-way ANOVA.

Table 3

Estimates of rate constant of ascorbic acid degradation and their standard errors (SD) obtained at different temperatures. Coefficient of determination of model fits $\left(R^{2}\right)$.

\begin{tabular}{lll}
\hline$T\left({ }^{\circ} \mathrm{C}\right)$ & $k \pm \mathrm{SD}$ & $R^{2}$ \\
\hline 25 & $0.0135 \pm 0.0009$ & 0.9599 \\
37 & $0.0550 \pm 0.0016$ & 0.8834 \\
50 & $0.1869 \pm 0.0042$ & 0.9731 \\
\hline
\end{tabular}

thermal and impact resistance, and a gas barrier effect. Other data in conflict with our results have been published by Abbasi and Niakousari (2007), who reported an AA retention of $57 \%$ and $36 \%$ in non-pasteurized lemon juice stored at $4{ }^{\circ} \mathrm{C}$ during 3 and 12 weeks, respectively. These authors described a rapid decrease in AA due to the oxidizing residual air layer trapped in the glass.

At the usual temperatures found in food storage at sales points $\left(25\right.$ and $37^{\circ} \mathrm{C}$ ), differences with respect to previous studies are also found. Pasteurized orange juice showed an AA retention of 50\% when stored for one week at $30^{\circ} \mathrm{C}$ (Polydera et al., 2005), and similar percentage retentions of $53 \%$ and $36 \%$ were reported in lemon juice stored at $28{ }^{\circ} \mathrm{C}$ during 3 and 12 weeks, respectively (Abbasi and Niakousari, 2007), versus $92.5 \%$ and $82.8 \%$ in our study $\left(25^{\circ} \mathrm{C}\right.$ during 4 and 12 weeks, respectively). These differences can be explained by the non-oxidative atmosphere present in our samples, as indicated above. Similarly, Burdurlu et al. (2006) recorded AA percentage retentions of $54.5-83.7 \%$ and $23.6-27 \%$ for different citrus juice concentrates (orange, lemon, grapefruit and tangerine) stored during 8 weeks at 28 and $37^{\circ} \mathrm{C}$, respectively. In our case, we recorded AA percentage retentions of $87.5 \%$ and $62.9 \%$ for samples stored during 8 weeks at 25 and $37^{\circ} \mathrm{C}$, respectively. On the other hand, we observed less AA retention in our samples stored for 32 weeks at $25^{\circ} \mathrm{C}(63.3 \%)$ and 16 weeks at $37{ }^{\circ} \mathrm{C}$ (36.1\%) than with extrapolated AA retention values reported by Palazón et al. (2009) for a glass-jarred apple-based beikost stored for 32 weeks at $23{ }^{\circ} \mathrm{C}(82.8 \%)$ and for 16 weeks at $37^{\circ} \mathrm{C}(59.7 \%)$. Although we do not have a plausible explanation for such differences in products of similar nature, differences in food matrix and in the packaging material could account for such discrepancies.

Finally, at forced storage temperatures $\left(50^{\circ} \mathrm{C}\right)$, a slightly higher AA retention (24.9\%) of our samples stored for 8 weeks at $50{ }^{\circ} \mathrm{C}$ was found in comparison with AA retention values reported in different citrus juice concentrates stored for 8 weeks at $45{ }^{\circ} \mathrm{C}(15.1-20 \%)$ (Burdurlu et al., 2006).

\subsection{Kinetics of ascorbic acid degradation}

Estimates of rate constant $(k)$ at each temperature $(25,37$ and $50{ }^{\circ} \mathrm{C}$ ) and their standard errors are reported in Table 3. The quality of model fits was assessed by the magnitude of the coefficients of determination $\left(R^{2}\right)$ and by analysis of the residuals (randomness and normality were verified; Fig. 1). The first-order kinetics model is the one that best explains AA retention in our study, in agreement with different studies including fruit juices (Abbasi and Niakousari, 2007; Burdurlu et al., 2006; Polydera et al., 2003, 2005; Rodrigo et al., 2003) and, most important, with the study of Palazón et al. (2009) involving an apple fruit-based beikost product.

Time (weeks)

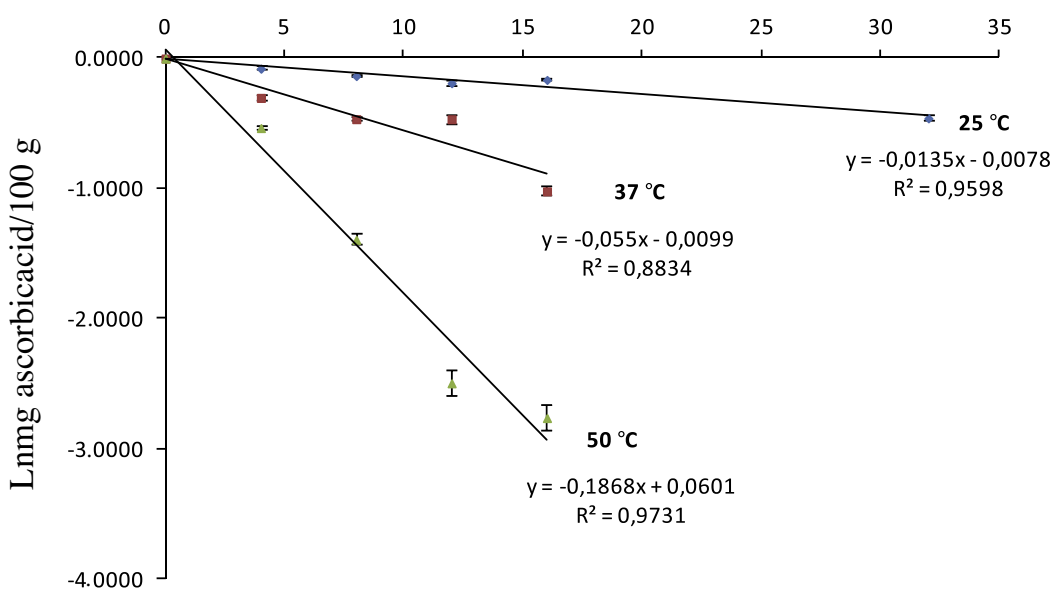

Fig. 1. Experimental data and model fits of ascorbic acid content throughout storage period, obtained at different temperatures. 


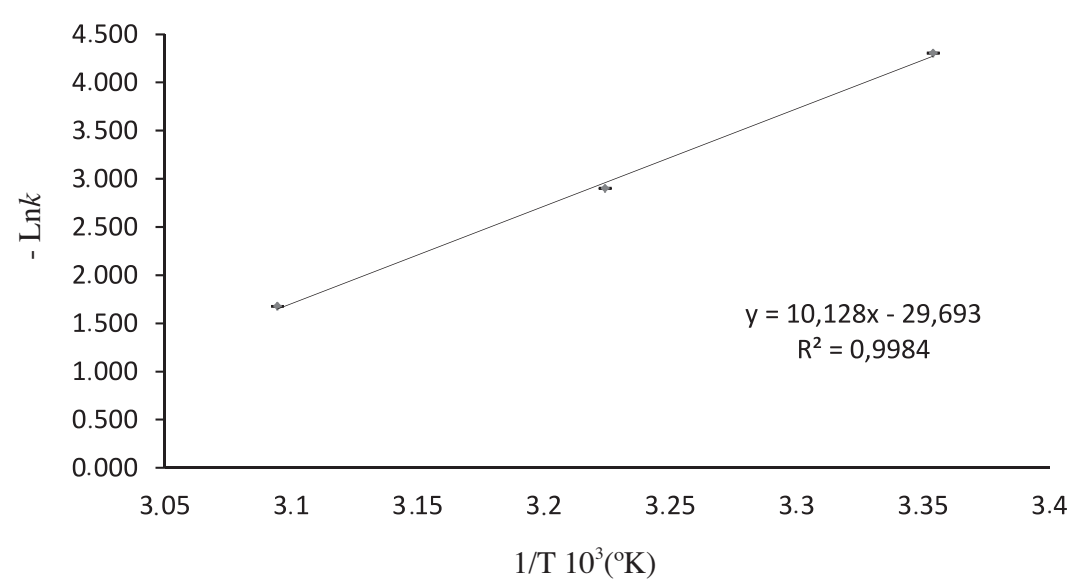

Fig. 2. Arrhenius plots of ascorbic acid degradation.

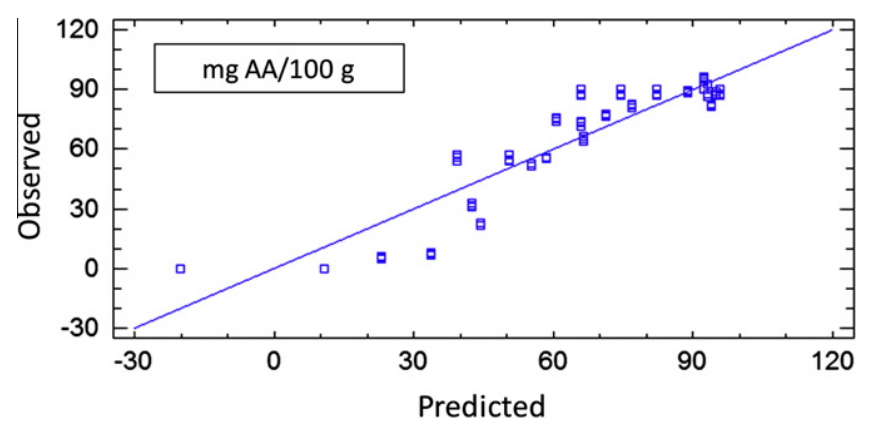

Fig. 3. Observed versus predicted values of ascorbic acid obtained by the model: Ascorbic acid $(\mathrm{mg} / 100 \mathrm{~g})=98.3-6.48 \times 10^{-1} \times$ Temperature $\left({ }^{\circ} \mathrm{C}\right)-5.37 \times 10^{-2}-$ $\times$ Temperature $\left({ }^{\circ} \mathrm{C}\right) \times$ time (weeks).

The values recorded for $k$ (weeks ${ }^{-1}$ ) obtained for the firstorder kinetics were $0.05415,0.2199$ and 0.7469 at 25,37 and $50{ }^{\circ} \mathrm{C}$, respectively, thus confirming the temperature-dependent degradation of AA. Fig. 2 graphically represents $-\ln k$ versus the inverse of temperature, yielding a linear plot with a slope representing $-\mathrm{Ea} / \mathrm{R}$. The obtained value of Ea was $20.11 \pm 0.33 \mathrm{kcal} \mathrm{mol}^{-1}$, which is in line with that reported in a homogenized apple-based beikost $\left(\mathrm{Ea}=18.6 \mathrm{kcal} \mathrm{mol}^{-1}\right.$ ) (Palazón et al., 2009). Likewise, the activation energy value of our study agrees with those noted for different citrus juice concentrates, with values of 25.16, 18.37 and $18.94 \mathrm{kcal} \mathrm{mol}^{-1}$ for orange, grapefruit and tangerine, respectively (Burdurlu et al., 2006). In contrast, our activation energy values is higher than the values found for pasteurized orange juices: $10.47 \mathrm{kcal} \mathrm{mol}^{-1}$ (Polydera et al., 2003) and $14.90 \mathrm{kcal} \mathrm{mol}^{-1}$ (Polydera et al., 2005).

The most robust predictive model for AA as a function of time and temperature $\left(R^{2}=0.8513\right)$ is shown in Fig. 3 and presents next equation: Vitamin $C \mathrm{mg} / 100 \mathrm{~g}=98.3-6.48 \times 10^{-1} \times$ Temperature $\left({ }^{\circ} \mathrm{C}\right)-5.37 \times 10^{-2} \times$ Temperature $\left({ }^{\circ} \mathrm{C}\right) \times$ time (weeks). The negative sign in the variables temperature and time $\times$ temperature indicates a decrease in AA content with increasing temperature $\left({ }^{\circ} \mathrm{C}\right)$ and time (weeks). The observed versus predicted plots of AA, and the corresponding equation, explains a high percentage of variability found in the retention of AA. However, as observed in Fig. 3, for samples in which there was no AA degradation with values ranging from $>40 \mathrm{mg}$ AA to $88 \mathrm{mg}$ AA (values obtained at usual storage temperatures at home and/or sales points: 4, 25 and $37^{\circ} \mathrm{C}$ ), this model is able to more accurately predict the values for AA.

\section{Conclusions}

The present study has contributed further data to the scarce background on the degradation kinetics of AA in fruit based-beikost products. It is important to emphasize that at the usual storage temperatures found in sales areas of products of this kind $\left(25^{\circ} \mathrm{C}\right)$, more than $70 \%$ of the $\mathrm{AA}$ is preserved during the common product turn-over period ( 16 weeks). In addition, it should be mentioned that no more than $50 \%$ of the AA was degraded at the end of the shelf-life of the products ( 32 weeks). Furthermore, we confirmed that AA degradation follows first-order kinetics, in agreement with other studies using samples of similar nature.

\section{Acknowledgements}

This work has been supported by ALNUT, S.L. V. Bosch is the holder of a grant from ALNUT, S.L. Thanks are also due to Dr. Gonzalo Clemente from the Statistics Department of the Polytechnic University of Valencia for his technical assistance with statistics.

\section{References}

Abbasi, A., Niakousari, M. 2007. Kinetics of ascorbic acid degradation in unpasteurized Iranian lemon juice and concentrate during regular storage conditions. Electronic Journal of Environmental, Agricultural and Food Chemistry 6, 1735-1741.

Agostoni, C., Decsi, T., Fewtrell, M., Goulet, O., Kolacek, S., Michaelsen, K.M., Moreno, L., Puntis, J., Rigo, J., Shamir, R., Szajewska, H., Turck, D., Van Goudoever, J., 2008. Complementary feeding: a commentary by the ESPGHAN Committee on Nutrition. Journal of Pediatric Gastroenterology and Nutrition 46, 99-110.

AOAC, 2000. Official Methods of Analysis of AOAC International, 17th ed. AOAC, Gaithersburg.

Ballabriga, A., Carrascosa, A., 2006. Alimentación complementaria y período del destete. In: Nutrición en la infancia y adolescencia. third ed. Ergon, Madrid, pp. $190-241$.

Burdurlu, H.S., Koca, N., Karadeniz, F., 2006. Degradation of vitamin C in citrus juice concentrates during storage. Journal of Food Engineering 74, 211-216.

Boselli, E., Velazco, V., Caboni, M.F., Lercker, G., 2001. Pressurized liquid extraction of lipids for the determination of oxysterols in egg-containing food. Journal of Chromatography A 917, 239-244.

Canet Parreño, W., 1996. Estabilidad e importancia de la vitamina C en vegetales congelados. Alimentación, Equipos y Tecnología 5, 75-87.

Directive 2006/125/EC of 5 December 2006 on processed cereal-based foods and baby foods for infants and young children, 2006. Official Journal of the European Union, vol. 339, pp. 16-35.

Folch, J., Lees, M., Sloane-Stanley, G.H., 1957. A simple method for the isolation and purification of total lipids from animal tissues. Journal of Biology Chemistry 226, 497-509.

Food and Nutrition Board, 2010. Dietary Reference Intakes (DRIs): Recommended Dietary Allowances and Adequate Intakes, Vitamins. Institute of Medicine of the National Academies. <http://www.nap.edu> (last accessed June 2012).

Hardman, T.M., 1989. Water and Food Quality. Elsevier, New York.

Labuza, T.P., 1982. Shelf-Life Dating of Foods. Food \& Nutrition Press, Inc., Westport. 
Labuza, T.P., Riboh, D., 1982. Theory and application of Arrhenius kinetics to the prediction of nutrient losses in foods. Food Technology 36, 66-74.

Martí, N., Mena, P., Cánovas, J.A., Micol, V., Saura, D., 2009. Vitamin C and the role of citrus juices as functional food. Natural product communications 4, 591-748.

Mercasa, 2011. Alimentación en España. Alimentación infantil. <http:// www.munimerca.es/mercasa/alimentacion_2011/3_info_sectores.html> (last accessed June 2012)

Palazón, M.A., Pérez-Conesa, D., Abellan, P., Ros, G., Romero, F., Vidal, M.L., 2009. Determination of shelf-life of homogenized apple-based beikost storage at different temperatures using Weibull hazard model. LWT - Food Science and Technology 42, 319-326.

Polydera, A.C., Stoforos, N.G., Taokis, P.S., 2003. Comparative shelf life study and vitamin $C$ loss kinetics in pasteurized and high pressure processed reconstituted orange juice. Journal of Food Engineering 60, 21-29.

Polydera, A.C., Stoforos, N.G., Taokis, P.S., 2005. Quality degradation kinetics of pasteurized and high pressure processed fresh Navel orange juice. Nutritional parameters and shelf life. Innovative Food and Emerging Technologies 6, 1-9.
Robertson, G.L., 1993. Structure and related properties of plastic polymers. Food Packaging. Dekker, New York, pp. 9-62.

Rodrigo, D., Arranz, J.I., Koch, S., Frígola, A., Rodrigo, M.C., Esteve, M.J., Calvo, C., Rodrigo, M., 2003. Physicochemical characteristic and quality of refrigerated Spanish orange-carrot juices and influence of storage conditions. Journal of Food Science 68, 2111-2116.

Ruiz, C., Alegria, A., Barbera, R., Farré, R., Lagarda, M.J., 1995. Direct determination of calcium, magnesium, potasium and iron in infant formulas by atomic spectroscopy. Comparison with dry and wet digestions methods. Die Nahrung 39, 497-504

Santos, P.H.S., Silva, M.A., 2008. Retention of vitamin C in drying processes of fruits and vegetables-A review. Drying Technology 26, 1421-1437.

Tikekar, R.V., Anantheswaran, R.C., LaBorde, L.F., 2011. Ascorbic acid degradation in a model apple juice system and in apple juice during ultraviolet processing and storage. Journal of Food Science 76 (2), 62-71.

Uddin, M.S., Hawlader, M.N.A., Ding, L., Mujumdar, A.S., 2002. Degradation of ascorbic acid in dried guava during storage. Journal of Food Engineering 51, 21-26. 